\title{
PENGARUH ANIMASI INTERAKTIF DENGAN MODEL EXPLICIT INSTRUCTION TERHADAP PRESTASI MATEMATIKA
}

\author{
Novita Soeryaningsih ${ }^{1}$, Besin Gaspar ${ }^{2}$, Soubar Isman $^{3}$ \\ 1,2,3Universitas Dr.Soetomo, novita.soeryaningsih@gmail.com
}

\begin{abstract}
Abstrak
Keberhasilan proses belajar tidak hanya ditentukan oleh guru atau, tetapi siswa ikut pula menentukan keberhasilan dalam proses pembelajaran matematika. Dalam kompetensi dasar perhitungan luas permukaan bangun gabungan adalah hal yang dianggap mempunyai tingkat kesulitan yang tinggi. Untuk itulah diperlukan sebuah media animasi interaktif GeoGebra yaitu sebuah aplikasi matematika bersumber terbuka yang dirancang khusus untuk tujuan pendidikan. Model pembelajaran Explicit Instruction adalah suatu pendekatan pembelajaran yang dirancang khusus untuk menunjang proses belajar siswa yang berkaitan dengan pengetahuan deklaratif dan prosedural yang tersruktur dengan baik yang diajarkan dengan pola selangkah demi selangkah. Dengan menggunakan media animasi interaktif dan model pembelajaran explicit instruction dapat meningkatkan prestasi belajar matematika utamanya pada perhitungan luas permukaan kubus dan balok. Peningkatan prestasi belajar yang dicapai oleh siswa yang pembelajarannya didukung penggunaan media animasi interaktif sebesar 21,5\%, sedangkan peningkatan prestasi belajar yang dicapai oleh siswa yang pembelajarannya didukung penggunaan model pembelajaran Explicit Instruction sebesar $23 \%$.
\end{abstract}

Kata kunci: animasi interaktif, model explicit instruction, prestasi belajar

\begin{abstract}
The success of the learning process is not only determined by the teacher or students, but students also determine success in the mathematics learning process. In the Basic Competence, the calculation of the combined surface area of the figure is things that are considered to have a high level of difficulty. For that we need an interactive animation media Geo Gebra, which is an application-based based specifically designed for educational purposes. Explicit Instruction learning model is a learning approach that is specifically designed to support student learning processes related to declarative and well-structured procedures that are taught in a step-by-step pattern. Using interactive animation media and explicit learning models can improve mathematics learning achievement, especially in calculating the surface area of cubes and blocks.
\end{abstract}

Keywords: interactive animation, explicit model of instruction, achievement 


\section{PENDAHULUAN}

Sistem pendidikan di Indonesia telah mengalami banyak perubahan dan perkembangan. Hal tersebut dapat dilihat dari adanya perubahan kurikulum dan perkembangan berbagai model dan strategi pembelajaran serta media pembelajaran yang tujuannya adalah untuk meningkatkan kualitas pendidikan. Dalam Undang-Undang Nomor 20 Tahun 2003 tentang Sistem Pendidikan Nasional menyatakan bahwa, pendidikan nasional bertujuan mengembangkan kemampuan dan membentuk watak serta peradaban bangsa yang bermartabat dalam rangka mencerdaskan kehidupan bangsa. Pendidikan bertujuan untuk mengembangkan potensi peserta didik agar menjadi manusia yang beriman dan bertaqwa kepada Tuhan Yang Maha Esa, berahlak mulia, sehat, berilmu, cakap, kreatif, mandiri, dan menjadi warga negara yang demokratis serta bertanggung jawab.

Menurut Undang Undang Sistem Pendidikan Nasional No.20 tahun 2003, ditegaskan bahwa pembelajaran adalah proses interaksi peserta didik dengan pendidik dan sumber belajar pada suatu lingkungan belajar. Keberhasilan siswa dalam melaksanakan segala proses pembelajaran tidak terlepas dari pengaruh guru sebagai pendidik dan siswa sebagai peserta didik. Sebagai pendidik, guru harus mampu dan trampil dalam mengelola proses pembelajaran dan meningkatkan mutu pendidikan seiring dengan berkembangnya ilmu pengetahuan dan teknologi saat ini. Oleh sebab itu belajar matematika pada siswa sekolah dasar menjadi wajib karena digunakan sebagai dasar untuk membentuk logika berfikir para siswa. Karena selama ini matematika dianggap sebagai salah satu bidang studi yang tidak banyak diminati siswa dan dirasa mempunyai tingkat kesulitan yang tinggi apalagi pada kompetensi dasar menjelaskan tentang perhituangan luas permukaan bangun ruang kubus dan balok, serta bangun gabungan dari beberapa bangun ruang serta perhitungan tentang volumenya. Untuk itulah diperlukan media yang mampu menjadikan jembatan berfikir anak agar lebih mengerti dan memahami akan materi yang diajarkan.

Pemilihan media animasi interaktif bangun ruang ini adalah merupakan salah satu pemanfaatan teknologi dengan menggunakan sebuah aplikasi bangun ruang yaitu Geo Gebra karena media ini merupakan hal yang baru bagi siswa sehingga memiliki daya tarik dan minat belajar pada siswa. Geo Gebra adalah sebuah apliikasi matematika bersumber terbuka yang dirancang khusus untuk tujuan pendidikan, dan menyatukan geometri, aljabar, kalkulus, bahkan probabilitas dan sumber daya statistik. Media animasi ini telah dipakai pada penelitian sebelumnya, namun penggunaan media animasi masih bersifat sederhana. Oleh sebab itu, tujuan penelitian ini adalah mencoba untuk mengembangkan media animasi tersebut lebih luas lagi yaitu dengan menggunakan aplikasi Geogebra untuk dapat meningkatkan prestasi belajar yang rendah pada siswa.

Kemudian untuk model pembelajaran yang digunakan adalah model pembelajaran explicit instruction, dimana pembelajaran ini diharapkan mampu meningkatkan pemahaman kepada setiap siswa karena model pembelajaran ini merupakan model pengajaran langsung yang memiliki proses belajar selangkahdemi selangkah. Disini peneliti ingin membuktikan bahwa model pembelajaran ini dapat digunakan pada semua bidang studi yang bersifat dalil pengetahuan agar proses berfikir siswa dapat mempunyai ketrampilan prosedural. Karena tujuan 
dari model pembelajaran ini adalah agar siswa dapat memahami serta benar-benar mengetahui pengetahuan secara menyeluruh dan aktif dalam suatu proses pembelajaran. Model pembelajaran ini sudah pernah diteliti sebelumnya yaitu pada bidang studi yang lain. Yang kesemuanya menunjukkan peningkatan hasil belajar siswa. Untuk itu, disini peneliti ingin membuktikan model pembelajaran tersebut diterapkan pada bidang matematika dan diharapkan dapat mampu meningkatkan prestasi belajar siswa yang sebelumnya rata-rata nilai siswa masih banyak dibawah KBM (Ketuntasan Belajar Minimal). Adapun rendahnya nilai matematika utamanya pada perhitungan luas permukaan kubus dan balok tersebut disebabkan oleh kurangnya variasi guru dalam pembuatan media dan penggunaan model pembelajaran sehingga siswa kurang berminat dan kurang aktif dalam mengikuti proses pembelajaran sehingga mengalami kesulitan.

Hamalik (1986) mengemukakan bahwa pemakaian media pembelajaran dalam proses belajar mengajar dapat membangkitkan keinginan dan minat yang baru, membangkitkan motivasi dan rangsangan kegiatan belajar dan bahkan membawa pengaruh-pengaruh psikologis terhadap siswa. Penggunaan media pembelajaran pada tahap orientasi pembelajaran akan sangat membantu keefektivan proses pembelajaran dan penyampaian pesan dan isi pelajaran saat itu. Selain membangkitkan motivasi dan minat siswa, media pembelajaran yang dapat membantu siswa meningkatkan pemahaman, menyajikan data yang menarik dan terpercaya, memudahkan penafsiran data, dan memadatkan informasi.

Sedangkan menurut Seels dan Glasgow dalam Arsyad (2004: 36) mengemukakan bahwa media animasi interaktif merupakan sistem media penyampaian yang menyajikan materi video rekaman dengan pengendalian komputer kepada penonton (mahasiswa) yang tidak hanya mendengar dan melihat video dan suara, tetapi juga memberikan respon yang aktif dan respon itu yang menentukan kecepatan dan sekuensi penyajian.

Dari beberapa beberapa teori diatas tentang media animasi interaktif maka dapatlah peneliti menarik kesimpulan bahwa media animasi interaktif merupakan media yang menarik dapat mampu meningkatkan konsentrasi dan minat siswa dalam melaksanakan proses pembelajaran serta dapat menjadikan alat transfer informasi yang sangat baik bagi siswa dikarenakan siswa dapat lebih cepat mengingat apa yang disampaikan oleh guru sehingga harapannya akan dapat meningkatkan pemahaman siswa yang berdampak pada prestasi belajar matematika utamanya bangun ruang pada perhitungan luas permukaan kubus dan balok pada siswa. Materi perhitungan luas permukaan kubus dan balok merupakan materi yang membutuhkan pemikiran tingkat tinggi bagi siswa.

Pengertian model pembelajaran Explicit Instruction menurut Arends (dalam Trianto, 2009:41) adalah suatu pendekatan pembelajaran yang dirancang khusus untuk menunjang proses belajar siswa yang berkaitan dengan pengetahuan deklaratif dan pengetahuan prosedural yang terstruktur dengan baik yang dapat diajarkan dengan pola selangkah demi selangkah. Model pembelajaran Explicit Instruction merupakan suatu pendekatan mengajar yang dapat membantu siswa dalam mempelajari ketrampilan dasar dan memperoleh informasi yang dapat diajarkan selangkah demi selangkah. Pendekatan ini disebut pengajaran langsung. Apabila dalam proses pembelajaran guru mempunyai tanggung jawab untuk mengidentifikasi tujuan pembelajaran dan tanggung jawab yang besar terhadap penstrukturan isi atau materi atau ketrampilan, menjelaskan kepada siswa, 
permodelan atau mendemonstrasikan yang dikombinasikan dengan latihan, memberikan kesempataan kepada siswa untuk berlatih menerapkan konsep atau ketrampilan yang telah dipelajari serta memberikan umpan balik Tujuannya adalah agar siswa dapat memahami serta benar-benar mengetahui pengetahuan secara menyeluruh dan aktif dalam suatu pembelajaran. Jadi model pembelajaran Explicit Instruction ini sangat cocok diterapkan dikelas dalam materi tertentu yang bersifat dalil pengetahuan agar proses berfikir siswa dapat mempunyai ketrampilan prosedural. Menurut Kandi dan Nur, sebagaimana dikutip oleh Trianto (2009: 41- 42) ada beberapa ciri-ciri model explicit instruction (pengajaran langsung) yaitu:

a) Adanya tujuan pembelajaran dan pengaruh mode pada siswa termasuk prosedur penilaian belajar.

b) Sintaks atau pola keseluruhan dan alur kegiatan pembelajaran dan

c) Sistem pengelolaan dan lingkungan belajar model yang diperlukan agar kegiatan pembelajaran tertentu dapat berlangsung dengan berhasil.

Selain itu, juga dalam explicit instruction (pengajaran langsung) harus memenuhi suatu persyaratan, antara lain (1) ada alat yang akan didemonstrasikan; (2) harus mengikuti tingkah laku mengajar (sintaks). Adapun langkah-langkah model pembelajaran Explicit Instructinatau pengajaran langsung. Menurut Kardi \& Nur (dalam Trianto 2009: 43) sintaks model pembelajaran Explicit Instruction ini disajikan dalam 5 tahap.

Tabel 1. Sintak Model Pengajaran Langsung

\begin{tabular}{c|l}
\multicolumn{1}{c|}{ Fase } & \multicolumn{1}{c}{ Peran Guru } \\
$\begin{array}{l}\text { Fase 1 } \\
\begin{array}{l}\text { Menyampaikan tujuan dan } \\
\text { mempersiapkan siswa }\end{array}\end{array}$ & $\begin{array}{l}\text { Guru menjelaskan informasi latar belakang } \\
\text { pelajaran, pentingnya pelajaran, mempersiapkan } \\
\text { siswa untuk belajar }\end{array}$ \\
\hline $\begin{array}{l}\text { Mendemonstrasikan } \\
\text { pengetahuan dan keterampilan }\end{array}$ & $\begin{array}{l}\text { Mendemonstrasikan ketrampilan dengan benar, } \\
\text { atau menyajikan informasi tahap demi tahap }\end{array}$ \\
$\begin{array}{l}\text { Fase 3 } \\
\text { Membimbing pelatihan }\end{array}$ & $\begin{array}{l}\text { Guru merencanakan dan memberi bimbingan } \\
\text { pelatihan awal }\end{array}$ \\
$\begin{array}{l}\text { Mengecek pemahaman dan } \\
\text { memberikan umpan balik }\end{array}$ & $\begin{array}{l}\text { Mengecek apakah siswa telah berhasil } \\
\text { melakukan tugasdengan baik, memberi umpan } \\
\text { balik }\end{array}$ \\
$\begin{array}{l}\text { Memberikan kesempatan } \\
\text { untuk pelatihan lanjutan dan } \\
\text { penerapan }\end{array}$ & $\begin{array}{l}\text { Guru mempersiapkan kesempatan melakukan } \\
\text { pelatihan lanjutan, dengan pelatihan khusus pada } \\
\text { penerapan kepadasituasi lebih komplek dalam } \\
\text { kehidupan sehari-hari. }\end{array}$
\end{tabular}

Model Pembelajaran Explisit Instruction (Pengajaran Langsung), menurut Kardi (dalam Huda, 2013: 186) dapat berbentuk ceramah, demonstrasi, pelatihan atau praktek, dan kerja kelompok. Model pembelajaran Explicit Instruction ini mempunyai beberapa kelebihan maupun kekurangan. Adapun Kelebihan yang dimiliki model pembelajaran Explicit Instruction adalah:

a) guru bisa mengendalikan isi materi dan urutan informasi yang diterima oleh siswa sehingga guru dapat mempertahankan fokus apa yang harus dicapai oleh siswa; 
b) dapat diterapkan secara efektifdalam kelas yang besar maupun kecil;

c) dapat digunakan untuk menekankan poin-poin penting atau kesulitan-kesulitan yang mungkin dihadapi siswa sehingga hal-hal tersebut dapat diungkapkan;

d) dapat menjadi cara yang efektif untuk mengajarkan informasi dan pengetahuan faktual yang terstruktur;

e) merupakan cara yang paling efektif untuk mengajarkan konsep dan ketrampilan-ketrampilan yang eksplisit kepada siswa yang berprestasi rendah;

f) dapat menjadi cara untuk menyampaikan informasi yang banyak dalam waktu relatif singkat dan dapat diakses secara setara oleh seluruh siswa;

g) memungkinkan guru untuk menyampaikan ketertarikan pribadi mengenai mata pelajaran (melalui presentasi yang antusias) yang dapat merangsang ketertarikan antusiasme siswa.

Sedangkan kelemahan model pembelajaran Explicit Instruction ini yaitu:

a) terlalu bersandar pada kemampuan siswa untuk mengasimilasikan informasi melalui kegiatan mendengarkan, mengamati, dan mencatat, sementara tidak semua siswa memiliki ketrampilan dalam hal-hal tersebut, sehingga guru masih harus mengajarkannya kepada siswa;

b) kesulitan untuk mengatasi perbedaan dalam hal kemampuan, pengetahuan awal, tingkat pembelajaran dan pemahaman, gaya belajar, atau ketertarikan siswa;

c) kesulitan siswa untuk mengembangakan ketrampilan sosial dan interpersonal yang baik;

d) kesuksesan strategi ini hanya bergantung pada penilaian dan antusias guru diruang kelas;

e) adanya berbagai hasil penelitian yang menyebutkan bahwa tingkat strukur dan kendali guru yang tinggi dalam kegiatan pembelajarandalam kegiatan pembelajaran, yang menjadi karakteristik strategi Explicit Instruction, dapat berdampak negatif terhadap kemampuan penyelesaian masalah, kemandirian, dan keingintahuan siswa.

Namun demikian, tujuan utama dari pemggunaan model pembelajaran explicit instruction yaitu memaksimalkan penggunaan waktu belajar siswa, sedangkan dampak pengajarannya adalah tercapainya ketuntasan muatan akademik dan ketrampilan, meningkatnya motivasi belajar serta meniingkatnya kemampuan siswa. Meskipun terdapat kelebihan dan kekurangan antara media animasi interaktif dan model pembelajaran explicit instruction, tetapi keduanya sama-sama mampu berperan dalam peningkattan prestasi belajar siswa. Menurut Winkel (1996:226) dalam Hamdani (2011), mengemukakan bahwa prestasi belajar merupakan bukti keberhasilan yang telah dicapai oleh seseorang. Dengan demikian, prestasi belajar merupakan hasil maksimum yang dicapai oleh seseorang setelah melaksanakan usaha-usaha belajar. Prestasi belajar harus memiliki 3 aspek yaitu kognitif, afektif dan psikomotor.

Pada dasarnya faktor yang mempengaruhi prestasi belajar ada 2 yaitu faktor internal dan faktor external. Faktor internal adalah faktor yang berasal dari siswa yang meliputi kecerdasan (intelegensi), faktor jasmaniah atau faktor fisiologis sikap, minat, bakat dan motivasi. Sedangkan Faktor external terdiri atas dua macam lingkungan sosial dan lingkungan non sosial. Yang termasuk dalam lingkungan sosial guru, kepala sekolah, staf administrasi, teman-teman sekelas, rumah tempat tinggal siswa, alat-alat belajar, dan lain-lain. Adapun yang termasuk 
dalam lingkungan non sosial adalah gedung sekolah, tempat tinggal dan waktu belajar. Berdasarkan uraian diatas maka dilaksanakan penelitian sebagai bahan perbaikan yang tujuannya untuk meningkatkan prestasi belajar matematika siswa utamanya pada materi perhitungan luas permukaan kubus dan balok.

\section{METODE}

Metode penelitian ini adalah penelitian kuantitatif. Metode penelitian kuantitatif adalah metode penelitian yang berlandaskan pada filsafat positivisme, digunakan untuk meneliti pada populasi atau sampel tertentu, pengumpulan data menggunakan instrumen penelitian, analisis data bersifat kuantitatif /statistik, dan tujuannya untuk menguji hipotesis yang telah ditetapkan. Berdasarkan permasalahan maka ditentukan variabel pertama yaitu media animasi interaktif $\left(\mathrm{X}_{1}\right)$ dan model pembelajaran explicit instruction $\left(\mathrm{X}_{2}\right)$ sebagai variabel bebas atau independen. Sedangkan prestasi belajar matematika pada materi sebagai variabel terikat (Y).

Penelitian ini dilaksanakan pada tanggal 7 Januari - 25 Januari 2019. Populasi yang gunakan dalam penelitian adalah siswa-siswi kelas VI SD Negeri Banyuajuh 3 Kamal-Bangkalan. Populasi adalah wilayah generalisasi yang terdiri atas: obyek yang mempunyai kualitas dan karakteristik tertentu yang ditetapkan oleh peneliti untuk dipelajari dan kemudian ditarik kesimpulannya. Sampel adalah bagian dari jumlah dan karakteristik yang dimiliki oleh populasi tersebut. Sedangkan sampel yang digunakan adalah siswa kelas VIA dan VIC masingmasing sebanyak 25 siswa.

Menurut Arikunto (2006:149) ada beberapa instrument yang namanya sama dengan metodenya, antara lain: Instrumen untuk metode tes adalah tes atau soal tes. Yang terdiri dari soal pretest dan posttest. Dalam penelitian ini peneliti menggunakan 10 soal isian. Soal yang dibuat berdasarkan pada kompetensi dasar pada Kurikulum 2013.

Analisis data yang digunakan pada penelitian ini yaitu dengan menggunakan uji validitas. Validitas adalah tingkat keandalan kesahihan alat ukur yang digunakan. Instrumen alat ukur yang dikatakan valid berarti menunjukkan alat ukur yang dipergunakan untuk mendapatkan data itu valid atau dapat digunakan untuk mengukur apa yang seharusnya diukur (Sugiyono, 2004: 137). Kemudian langkah selanjutnya dengan uji normalitas data. Analisis data awal digunakan untuk mengetahui apakah kedua sampel yang digunakan berdistribusi normal atau tidak (Sugiyono, 2015). Untuk mengetahui apakah kedua variabel independen berpengaruh secara serempak terhadap variabel dependen digunakan Uji $\mathrm{T}$ dan Uji One Way Anova. Sedangkan mana diantara kedua variabel independen yang lebih dominan dapat diketahui dari perbedaan nilai mean dari keduanya.

\section{HASIL DAN PEMBAHASAN}

Penelitian dilaksanakan di SD Negeri Banyuajuh 3 Kelas VI. Dengan jumlah siswa sebanyak 50 siswa yang terdiri dari 25 siswa sebagai kelompok 1 yaitu kelas VIA dengan penggunaan animasi interaktif bangun ruang. Sedangkan kelompok 2 adalah kelas VIC dengan menggunakan model pembelajaran explicit instruction. Data berupa prestasi belajar siswa berupa aspek kognitif diperoleh dari nilai siswa sebelum dan sesudah diberi perlakuan yaitu berupa soal pretest dan posttes sebanyak 10 soal. 
Dari hasil perhitungan data dari penelitian yang dilakukan di dapat hasil dari posttest media pembelajaran animasi, diperoleh nilai tertinggi sebesar 90 dan nilai terendah 72 sedangkan nilai rata-rata 81,2. Sedangkan nilai rata-rata pada pretest $\left(\mathrm{X}_{1}\right)$ sebesar 63,76, standar devisiasi $(\mathrm{s})$ sebesar 4,400 dan varians $\left(\mathrm{s}^{2}\right)$ sebesar 19,357. Dari hasil perhitungan data penelitian yang di dapat dari posttest model pembelajaran Explisit Instruction diperoleh nilai tertinggi sebesar 90 dan nilai terendah 75 sedangkan nilai rata-rata 83,08. Sedangkan nilai rata-rata hasil pretest $\left(\mathrm{X}_{2}\right)$ sebesar 63,96, standar devisiasi (s) sebesar 4,800 dan varians $\left(\mathrm{s}^{2}\right)$ sebesar 23,040.

Hasil perhitungan uji reliabilitas skala hasil belajar (posttest) sebesar 0,766. Hal ini membuktikan bahwa hasil skala dari hasil belajar memiliki tingkat reliabilitas yang tinggi dengan kriteria pengujian yang mana apabila $r$ Alpha $>r$ tabel maka dinyatakan reliable ( $\mathrm{r}$ Alpha $0,766>\mathrm{r}_{\text {tabel }} 0.396$ ). Pengujian dilakukan pada taraf kepercayaan 0,05 dari hasil uji validitas dapat disimpulkan bahwa tes tulis atau posttest antara media dan model pembelajaran tersebut berdistribusi normal karena memenuhi kriteria, kelas dengan perlakuan media pembelajaran Animasi Interaktif $0,036>0,05$ dan pada kelas dengan perlakuan model pembelajaran Explisit Instruction 0,066 > 0,05.

Berdasarkan tabel 4.10 hasil uji One Way ANOVA menyatakan bahwa nilai sig. sebesar $0,025>0,05$ yang mengindikasikan bahwa terdapat pengaruh yang signifikan pada prestasi belajar matematika pada materi bangun ruang dengan diberikan 2 perlakuan antara media pembelajaran animasi interaktif dan model explisit instruction. Jadi $\mathrm{H}_{0}$ ditolak dan $\mathrm{H}_{\mathrm{a}}$ diterima dimana hasil ANOVA tersebut bersifat menyeluruh yaitu secara bersamaan memiliki data yang signifikan. Data diatas dapet dilihat dari hasil $F_{\text {hitung dimana apabila } F_{\text {hitung }}>F_{\text {tabel }}}$ maka $\mathrm{H}_{0}$ ditolak dan $\mathrm{H}_{\mathrm{a}}$ diterima dalam artian antara media pembelajaran dan model pembelajaran tersebut berpengaruh terhadap hasil belajar matematika pada materi bangun ruang dan sebaliknya apabila $\mathrm{F}_{\text {hitung }}<\mathrm{F}_{\text {tabel }}$ maka $\mathrm{H}_{0}$ diterima dan $\mathrm{H}_{\mathrm{a}}$ ditolak artinya tidak ada pengaruh antara media danmodel pembelajran terhadap prestasi belajar matematika pada materi bangun ruang. Hasil pengujian pada tabel diatas menunjukan bahwa $F_{\text {hitung }}$ sebesar 5,330 > $F_{\text {tabel, yang artinya terdapat }}$ pengaruh media pembelajaran animasi interaktif dan model pembelajaran explisit instruction terhadap prestasi belajar matematika pada materi bangun ruang siswa kelas VI di SDN Banyuajuh 3 Kamal.

Berikut ini adalah table hasil pengujian hasil belajar matematika pada masing-masing model pembelajaran yang dilakukan pada materi bangun ruang siswa kelas VI di SDN Banyuajuh 3 Kamal: 
Tabel 2. Pengujian Hasil Belajar pada Masing-masing Model Pembelajaran

\begin{tabular}{|l|r|r|r|r|r|r|r|r|}
\hline & N & Mean & \multicolumn{1}{c|}{$\begin{array}{c}\text { Std. } \\
\text { Deviati } \\
\text { on }\end{array}$} & $\begin{array}{c}\text { Std. } \\
\text { Error }\end{array}$ & \multicolumn{2}{|c|}{$\begin{array}{r}\text { 95\% Confidence } \\
\text { Interval for Mean }\end{array}$} & $\begin{array}{r}\text { Mini } \\
\text { mum }\end{array}$ & $\begin{array}{r}\text { Maxi } \\
\text { mum }\end{array}$ \\
\cline { 5 - 7 } & & & $\begin{array}{r}\text { Lower } \\
\text { Bound }\end{array}$ & $\begin{array}{r}\text { Upper } \\
\text { Bound }\end{array}$ & & \\
\hline $\begin{array}{l}\text { Animasi } \\
\text { interaktif } \\
\text { explisit } \\
\text { insruction }\end{array}$ & 25 & 81.20 & 3.266 & .653 & 79.85 & 82.55 & 76 & 88 \\
Total & 50 & 82.14 & 3.003 & .425 & 81.29 & 82.99 & 76 & 89 \\
\hline
\end{tabular}

Berdasarkan hasil pengujian pada Tabel 2 dapat disimpulkan bahwa antara media pembelajaran animasi interaktif dan model pembelajaran explisit instruction yang lebih dominan berpengaruh terhadap prestasi belajar matematika pada materi bangun ruang di kelas VI di SDN Banyuajuh 3 Kamal yaitu model pembelajaran explisit instruction, hal ini dapat dilihat pada hasil rata-rata (mean) antara media pembelajaran animasi interaktif memiliki rata-rata 81,20 sedangkan model pembelajaran explisit instruction memiliki rata-rata 83,08.

Nilai rata-rata siswa sebelum menggunakan media animasi interaktif yaitu 63,76 dengan mediannya 63. Sedangkan nilai rata-rata siswa setelah menggunakan media animasi interaktif sebesar 81,2 dengan median 82. Nilai tertinggi pada pretest 72 dan posttest meningkat menjadi 90. Dengan demikian terdapat peningkatan sebesar 21,5\%. Apabila diukur dari nilai siswa yang melampaui KKM (Kriteria Ketuntasan Minimal) maka didapat hasil sebelum menggunakan media animasi interaktif sejumlah 13 siswa. Sedangkan sesudah menggunakan media animasi interaktif sejumlah 25 siswa dari 25 jumlah siswa yang diteliti.

Nilai rata-rata siswa sebelum menggunakan model pembelajaran Explicit Instruction sebasar 63,96 dengan median 65. Sedangkan nilai rata-rata siswa setelah menggunakan model pembelajaran Explicit Instruction meningkat menjadi 83,08 dengan median 85. Dengan demikian, terdapat peningkatan sebesar $23 \%$. Apabila diukur dari nilai siswa yang melampaui KKM (Kriteria Ketuntasan Minimal) maka didapat hasil sebelum menggunakan model pembelajaran Explicit Instruction sejumlah 12 siswa. Sedangkan sesudah menggunakan model pembelajaran Explicit Instruction sejumlah 25 siswa dari 25 jumlah siswa yang diteliti.

Hal ini membuktikan bahwa penggunaan model pembelajaran Explicit Instruction sangat berpengaruh pada peningkatan prestasi belajar siswa. Hal ini sesuai dengan tujuan utama model pembelajaran ini yaitu memaksimalkan waktu belajar siswa sehingga berdampak pada tercapainya ketuntasan belajar siswa serta meningkatkan kemampuan siswa. Ada pun persamaan dari kedua variabel diatas yaitu antara penggunaan media pembelajaran animasi interaktif dan penggunaan model pembelajaran explicit instruction, sama-sama menunjukkan adanya peningkatan pada prestasi belajar matematika pada materi bangun ruang. 


\section{SIMPULAN DAN SARAN}

Berdasarkan pada serangkaian pembahasan bab sebelumnya dan hasil analisis data dari hasil penelitian yang telah dilakukan pada siswa kelas VIA dan VIC SDN Banyuajuh 3, Kecamatan Kamal - Bangkalam serta data yang telah disajikan, dapatlah diambil kesimpulan sebagai berikut:

1) Ada perbedaan antara prestasi belajar yang dicapai oleh siswa yang pembelajarannya didukung penggunaan media animasi interaktif yaitu peningkatan pada nilai rata-rata siswa sebelum dan setelah menggunakan menggunakan media animasi interaktif. Nilai rata-rata siswa sebelum menggunakan media animasi interaktif yaitu 63,76 dengan mediannya 63.

Sedangkan nilai rata-rata siswa setelah menggunakan media animasi interaktif sebesar 81,2 dengan median 82. Nilai tertinggi pada pretest 72 dan posttest meningkat menjadi 90.

Dengan demikian terdapat peningkatan sebesar 21,5\%. Apabila diukur dari nilai siswa yang melampaui KKM (Kriteria Ketuntasan Minimal) maka didapat hasil sebelum menggunakan media animasi interaktif sejumlah 13 siswa. Sedangkan sesudah menggunakan media animasi interaktif sejumlah 25 siswa dari 25 jumlah siswa yang diteliti.

2) Ada perbedaan antara prestasi belajar yang dicapai oleh siswa yang pembelajarannya didukung penggunaan model pembelajaran Explicit Instruction yaitu peningkatan pada nilai rata-rata siswa sebelum dan setelah menggunakan model pembelajaran Explicit Instruction. Nilai rata-rata siswa sebelum menggunakan model pembelajaran Explicit Instruction sebasar 63,96 dengan median 65. Sedangkan nilai rata-rata siswa setelah menggunakan model pembelajaran Explicit Instruction meningkat menjadi 83,08 dengan median 85.

Dengan demikian, terdapat peningkatan sebesar $23 \%$. Apabila diukur dari nilai siswa yang melampaui KKM (Kriteria Ketuntasan Minimal) maka didapat hasil sebelum menggunakan model pembelajaran Explicit Instruction sejumlah 12 siswa. Sedangkan sesudah menggunakan model pembelajaran Explicit Instruction sejumlah 25 siswa dari 25 jumlah siswa yang diteliti.

Hal ini membuktikan bahwa penggunaan model pembelajaran Explicit Instruction sangat berpengaruh pada peningkatan prestasi belajar siswa. Hal ini sesuai dengan tujuan utama model pembelajaran ini yaitu memaksimalkan waktu belajar siswa sehingga berdampak pada tercapainya ketuntasan belajar siswa serta meningkatkan kemampuan siswa. Ada pun persamaan dari kedua variabel diatas yaitu antara penggunaan media pembelajaran animasi interaktif dan penggunaan model pembelajaran explicit instruction, sama-sama menunjukkan adanya peningkatan pada prestasi belajar matematika pada materi bangun ruang siswa kelas VI SD Negeri Banyuajuh 3 Kamal.

3) Sedangkan berdasarkan Tabel 2 menunjukkan bahwa peningkatan mean pada penggunaan media animasi interaktif sebesar 81,20 dan penggunaan model pembelajaran explicit instruction sebesar 83,08. Maka dalam hal ini dapatlah diambil kesimpulan bahwa model pembelajaran explicit instruction dinyatakan lebih dominan. 


\section{DAFTAR PUSTAKA}

Arsyad, Azhar, 2009. Media Pembelejaran. Jakarta, Rajawali Pers.

Hamdani, 2011, Strategi Belajar Mengajar, Jakarta, Pustaka Setia.

Huda, Miftahul, 2013. Model-Model Pengajaran dan Pembelajaran: Isu-Isu Metodis dan paragdimatis, Yogjakarta, Penerbit Pustaka Pelajar.

Sanjaya, Wina, 2013, Strategi Pembelajaran: Berorientasi Standar Proses Pendidian, Jakarta, Kencana Prenada Media Group.

Sugiyono, 2011. Metode Penelitian Kuantitatif Kualitatif dan $R \&$ D. Jakarta, Penerbit Alfabeta.

Trianto, 2009. Mendesain Model Pembelajaran Inovatif - Progresif. Jakarta, Penerbit Kencana Prenada Media Grup. 